\title{
UJI TEKNO-EKONOMI ALAT PEMOTONG TAHU YANG ERGONOMIS
}

\author{
Techno-Economic Test of Ergonomic Tofu Cutter
}

\author{
Renny Eka Putri ${ }^{*}$, Fadhli Anas, Ashadi Hasan
}

Jurusan Teknik Pertanian dan Biosystem Fakultas Teknologi Pertanian

Universitas Andalas, Kampus Limau Manis-Padang 25163

* rennyekaputri@ae.unand.ac.id

\begin{abstract}
Process of cutting tofu activities carried out so far is still manually using a ruler and knife. The objective of the study is to design semi-mechanical tofu cutting system and technical analysis of tofu cutting system. This study tested using 2 treatments with 5 replications for each treatment and tests the tofu cutting P1 (size $10 \mathrm{~cm} \times 5 \mathrm{~cm})$ and $P 2(5 \mathrm{~cm} \times 5 \mathrm{~cm})$. The results show with in 2 treatments for the effective working capacity is $126.2 \mathrm{~kg} / \mathrm{hour}$ and $119.64 \mathrm{~kg} / \mathrm{hour}$, theoretical capacity $145.73 \mathrm{~kg} / \mathrm{hour}$, tool efficiency $86.578 \%$ and $82.08 \%$, perfect cut percentage $88,54 \%$ and $89,30 \%$, the percentage of yield damage is $5.16 \%$ and $3.96 \%$, yield loss is $6.29 \%$ and $6.72 \%$, operator power is 24.61 watts and 24.27 watts. Based on economic analysis carried out, the basic cost for cutting process is Rp. 5/kg. This semimechanical tofu cutting tool is more efficient than manually.
\end{abstract}

Keywords : tofu, capacity, cutting tool

\begin{abstract}
ABSTRAK
Industri rumah tangga masih melakukan pemotongan tahu secara manual dengan mengggunakan penggaris dan pisau. Dalam membuat alat mesin pertanian sangat dibutuhkan aspek ergonomis dari alat tersebut. Alat yang dibuat dapat memberikan kenyamanan pada para pekerja nantinya. Penelitian ini bertujuan untuk melakukan pengembangan alat pemotong tahu semi mekanis yang ergonomis untuk meningkatkan efektivitas waktu potong tahu, analisis teknis alat pemotong tahu. Penelitian ini meliputi pengembagan alat pemotong tahu semi mekanis yang menggunakan 2 perlakuan dengan 5 kali ulangan setiap perlakuan dan melakukan uji terhadap alat pemotong tahu dengan kadar air P1 $(10 \mathrm{~cm} \times 5 \mathrm{~cm})$ dan P2 $(5 \mathrm{~cm} \times 5$ $\mathrm{cm}$ ) berturut-turut $82,19 \%$ dan $80,35 \%$. Hasil penelitian dari pengujian alat dengan 2 perlakuan menghasilkan kapasitas kerja efektif alat 126,2 kg/jam dan 119,64 kg/jam, kapasitas teoritis $145,73 \mathrm{~kg} / \mathrm{jam}$, efesiensi alat $86,578 \%$ dan $82,08 \%$, persentase terpotong sempurna $88,54 \%$ dan $89,30 \%$, persentase kerusakan hasil $5,16 \%$ dan $3,96 \%$, kehilangan hasil $6,29 \%$ dan $6,72 \%$, daya operator 24,61 watt dan 24,27 watt. Alat ini diharapkan dapat membantu industri rumah tangga dalam proses pemotongan tahu.
\end{abstract}

Kata Kunci : tahu, kapasitas, alat pemotong. 


\section{PENDAHULUAN}

Tahu merupakan salah satu produk hasil olahan dari kedelai. Tahu adalah salah satu makanan tradisional khas Indonesia yang diproduksi dan dikonsumsi secara turun-temurun. Pada beberapa industry rumah tangga di Sumatera Barat, kegiatan pemotongan tahu masih belum efisien karena pemotongan tahu masih manual menggunakan penggaris dan pisau. Proses ini mengharuskan pekerja menunduk untuk memotong tahu yang dapat mengakibatkan pekerja lebih cepat mengalami kelelahan dan sakit punggung. Selain itu proses pemotongan tahu yang menggunakan penggaris dan pisau juga dapat memakan waktu yang lama dan kemungkinan terjadi kecacatan pada produk lebih sering. Permasalahan ini dapat diselesaikan dengan membuat alat pemotong tahu semi mekanis yang telah ditentukan ukuran potong sehingga waktu yang digunakan lebih cepat.

Pengamatan dilakukan terhadap manusia, lingkungan, mesin, peralatan dan bahan baku yang digunakan untuk proses produksi karena semua itu saling berinteraksi, sehingga memerlukan pemahaman tentang manusia dan fasilitas kerja yang digunakannya. Pekerjaan dengan beban yang berat dan perancangan fasilitas kerja yang tidak ergonomis mengakibatkan pengerahan tenaga yang berlebihan, juga postur kerja yang salah dapat mengakibatkan ketidaknyamanan dalam bekerja, hal ini berakibat timbulnya keluhan dan kelelahan dini [1] [2].

Alat pemotong tahu yang sudah berkembang pada industri rumah tangga masih menggunakan alat-alat yang seadanya saja seperti: pisau dapur, penggaris kayu. Kapasitas kerja dari alat yang digunakan pada industri rumahan sekarang ini tergantung kepada pekerjanya sendiri. [3] melakukan perancangan alat pemotong tahu dengan metode benchmarking. Data menunjukkan dengan menggunakan alat dengan bahan stainless steel, dengan ukuran $48 \mathrm{~cm}$ x $46,40 \mathrm{~cm}$ x $5 \mathrm{~cm}$ dan berat $3,7 \mathrm{~kg}$ yang dapat menghasilkan waktu pemotongan selama 47 detik.

Pada alat yang akan dikembangkan ini, akan menitik beratkan pada aspek rancangan yang ergonomis. Kelebihan menggunakan ilmu antropometri yaitu dapat mengetahui dan menyesuaikan bentuk serta ukuran yang sesuai dengan keadaan operator. Dengan penerapan ilmu antropometri operator dapat mengoperasikan alat dengan nyaman dan dapat mengurangi kelelahan saat bekerja.

Adapun tujuan yang ingin dicapai dalam penelitian ini yaitu :

1. Melakukan pengembangan alat pemotong tahu semi mekanis untuk meningkatkan efektivitas waktu potong tahu.

2. Melakukan analisis teknis alat pemotong tahu.

3. Melakukan analisis ekonomi alat pemotong tahu.

\section{METODOLOGI PENELITIAN}

Pengembangan alat pemotong tahu semi mekanis disusun oleh beberapa komponen seperti rangka utama, kawat pemotong, media penampung irisan tahu. Proses pemotongan tahu di UD Super Indra dengan ukuran panjang potongan tahu $10 \mathrm{~cm}$, lebar $5 \mathrm{~cm}$, dan 
tinggi $3,5 \mathrm{~cm}$ dan luas tahu yang siap untuk dipotong yaitu $40 \mathrm{~cm} \times 40 \mathrm{~cm}$. Ukuran pemotongan tahu dilakukan dengan 2 perlakuan, perlakuan pertama yaitu $10 \mathrm{~cm}$ x $5 \mathrm{~cm}$ dan perlakuan kedua $5 \mathrm{~cm}$ x $5 \mathrm{~cm}$. Masing-masing perlakuan di ulang sebanyak 5 kali. Untuk satu ulangan menggunakan 5 cetakan tahu berukuran $40 \mathrm{~cm}$ x $40 \mathrm{~cm}$. Tahapan penelitian adalah sebagai berikut:

\section{Analisis Rancangan Struktural}

\section{Rangka Utama}

Rangka utama terbuat dari besi hollow dengan ukuran $(30 \mathrm{~mm} \times 30 \mathrm{~mm}$ $\mathrm{x}$ 1,2 $\mathrm{mm}$ ) yang dengan alasan memilih bahan besi dari hollow agar nantinya alat yang akan dirancang memiliki ketahanan dan kekuatan untuk menopang beban. Bentuk kaki alat ini dirancang dengan bentuk persegi panjang dengan ukuran Tinggi rangka alat adalah $40 \mathrm{~cm}$, dan lebar alat $45 \mathrm{~cm} \times 45 \mathrm{~cm}$. Gambar rangka utama ini dapat dilihat pada Gambar 1.

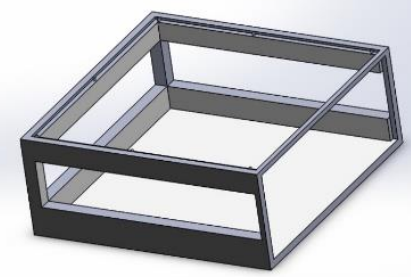

Gambar 1. Rangka Utama

\section{Senar Pemotong}

Kawat/ senar gitar adalah bagian yang berfungsi untuk memotong tahu, banyak kawat pemotong/ senar gitar untuk perlakuan pertama yaitu 10 kawat dengan ukuran potongan tahu $10 \mathrm{~cm}$ x 5 $\mathrm{cm}$ dan perlakuan kedua sebanyak 14 kawat untuk ukuran potongan tahu $5 \mathrm{~cm}$ x $5 \mathrm{~cm}$. Gambar senar pemotong dapat di lihat pada Gambar 2.

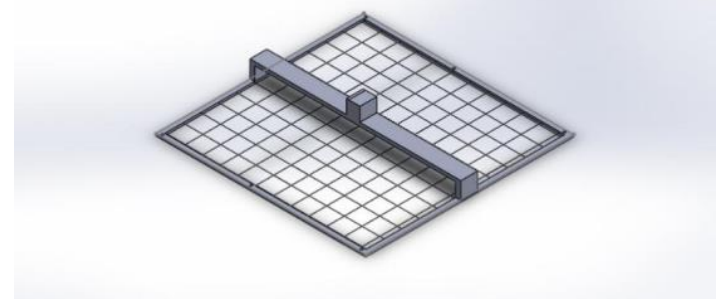

Gambar 2. Senar Pemotong

\section{Tuas Pemotong}

Tuas pemotong berfungsi untuk menekan rangka senar pemotong yang terletak pada bagian paling atas dari rangka utama dan rangka senar pemotong, tuas pemotong dapat dilihat pada Gambar 3.

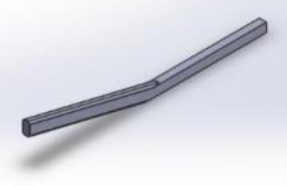

Gambar 3. Tuas Pemotong

\section{Analisis Rancangan Fungsional}

Analisis rancangan fungsional ini untuk menentukan komponenkomponen utama yang ada pada alat, diantaranya adalah:

1. Kerangka utama berfungsi sebagai kerangka dasar tempat dudukan komponen-komponen alat.

2. Kawat pemotong berfungsi sebagai alat memotong bahan yang akan di potong.

3. Bagian Penampung Tahu berfungsi sebagai tempat penampung tahu yang setelah di potong. 


\section{Analisis Gaya Alat}

Analisis gaya alat yang bertujuan untuk mengetahui gaya yang bekerja. Menghitung gaya yang dibutuhkan untuk memotong tahu, uji kekerasan tahu yang dilakukan dengan alat Texture Analizer dengan 5 buah sampel tahu. Sebelum dilakukannya pembuatan alat, dilakukan pengujian kekerasan tahu mengguakan alat ukur Texture Analiyzer. Berdasarkan pengujian dengan menggunakan Texture Analizer, Gaya yang didapatkan untuk memotong tahu yaitu $0,83 \mathrm{~N}$ seperti yang terdapat pada Tabel 1 .

Tabel 1. Uji Kekerasan Tahu

\begin{tabular}{cccc}
\hline Sampel & $\mathrm{Gr}$ & $\mathrm{Kg}$ & $\mathrm{N}$ \\
\hline 1 & 78,5 & 0,0785 & 0,769 \\
2 & 79,0 & 0,079 & 0,774 \\
3 & 91,0 & 0,091 & 0,892 \\
4 & 81,0 & 0,081 & 0,794 \\
5 & 94,0 & 0,094 & 0,921 \\
Rata-rata & 84,7 & 0,0847 & 0,83 \\
\hline
\end{tabular}

Sumber : Data Hasil Penelitian

Gaya yang didapatkan dapat dihitung dengan persamaan berikut : $\mathrm{F}=\mathrm{m} \times \mathrm{g}$

Diketahui :

$$
\begin{aligned}
& \mathrm{m}=84,7 \mathrm{gr}=0,0847 \mathrm{~kg} \\
& \mathrm{~g}=9,8 \mathrm{~m} / \mathrm{s} \\
& \mathrm{F}=0,0847 \mathrm{~kg} \times 9,8 \mathrm{~m} / \mathrm{s} \\
& =0,83 \mathrm{~N}
\end{aligned}
$$

Dengan :

$$
\begin{aligned}
& \mathrm{F}=\text { Gaya untuk memotong }(\mathrm{N}) \\
& \mathrm{m}=\text { Massa }(\mathrm{kg}) \\
& \mathrm{g}=\operatorname{Gravitasi}(\mathrm{m} / \mathrm{s})
\end{aligned}
$$

Untuk menghitung tekanan yang akan diberikan terhadap tahu, agar tahu bisa terpotong dengan ukuran potongan $10 \mathrm{~cm} \times 5 \mathrm{~cm}$ dan $5 \mathrm{~cm} \times 5 \mathrm{~cm}$, dengan menggunakan persamaan berikut :
$\mathrm{P}=\mathrm{F} / \mathrm{A}$

Diketahui :

$$
\mathrm{F}=0,83 \mathrm{~N}
$$

Diameter senar $=0,36 \mathrm{~mm}$

$$
=0,00036 \mathrm{~m}
$$

Panjang senar $=47 \mathrm{~cm}$ $=0,47 \mathrm{~m}$

$\mathrm{A}=$ Diameter senar $\mathrm{x}$ Panjang senar

$$
=0,00036 \mathrm{~m} \times 0,47 \mathrm{~m}
$$$$
=1,692 \times 10^{-4} \mathrm{~m}^{2}
$$

$\mathrm{P}=\mathrm{F} / \mathrm{A}$

$$
=0,83 \mathrm{~N} / 1,692 \times 10^{-4} \mathrm{~m}^{2}
$$$$
=4905,437 \mathrm{~N} / \mathrm{m}^{2}
$$

Dimana :

$$
\begin{aligned}
& \mathrm{P}=\text { Tekanan }\left(\mathrm{N} / \mathrm{m}^{2}\right) \\
& \mathrm{F}=\text { Gaya }(\text { Newton}) \\
& \mathrm{A}=\text { Luas penampang senar }\left(\mathrm{m}^{2}\right)
\end{aligned}
$$

Menghitung regangan senar untuk memotong tahu dengan menggunakan persamaan sebagai berikut :

Regangan $=\Delta l / l o$

Diketahui :

$$
\begin{aligned}
& \Delta l=0 \mathrm{~m} \\
& l \mathrm{o}=47 \mathrm{~cm}=0,47 \mathrm{~m}
\end{aligned}
$$

$$
\text { Regangan }=\frac{0 \mathrm{~m}}{0,47 \mathrm{~m}}
$$$$
=0
$$

Dimana :

$$
\begin{aligned}
& \Delta l=\text { Perubahan Panjang }(\mathrm{m}) \\
& l \mathrm{o}=\text { Panjang Awal }(\mathrm{m})
\end{aligned}
$$

\section{Pengamatan}

Adapun pengamatan yang akan dilakukan pada penelitian ini adalah:

\section{Kadar Air Tahu}

Pengujian kadar air tahu dilakukan dengan dua perlakuan yaitu pengujian sebelum tahu terpotong dan tahu setelah terpotong. Pengujian kadar air dilakukan dengan menggunakan oven pada suhu $105{ }^{\circ} \mathrm{C}$. Perhitungan 
persentase kadar air tahu secara matematis dapat di hitung menggunakan persamaan berikut :

$$
\mathrm{KA}=\frac{B-C}{B-A} \times 100 \%
$$

Keterangan :

$$
\begin{aligned}
\mathrm{KA} & =\text { Kadar Air }(\%) \\
\mathrm{A} & =\text { Berat cawan kosong }(\mathrm{g}) \\
\mathrm{B} & =\text { Berat cawan }+ \text { sampel } \\
& \text { sebelum dikeringkan dengan } \\
& \text { oven }(\mathrm{g}) \\
\mathrm{C} \quad & =\text { Berat cawan }+ \text { sampel } \\
& \text { setelah dikeringkan dengan } \\
& \text { oven }(\mathrm{g})
\end{aligned}
$$

\section{Kapasitas Kerja Efektif}

Kapasitas kerja efektif alat pemotong tahu secara matematis dapat dihitung dengan menggunakan persamaan berikut :

$$
\mathrm{KKE}=\frac{B}{t}
$$

Keterangan :

KKE $=$ Kapasitas Kerja Efektif pemotong tahu $(\mathrm{kg} / \mathrm{Jam})$

$\mathrm{B}=$ Jumlah hasil pemotongan $(\mathrm{kg})$

$\mathrm{t}=$ Lamanya waktu pemotongan (Jam)

\section{Kapasita Teoritis}

Perhitungan kapasitas teoritis pada alat pemotong tahu dapat dihitung dengan menggunakan persamaan berikut:

$$
\mathrm{KKT}=(\mathrm{p} \times 1) \times \mathrm{BV} \times \mathrm{v}
$$

Keterangan :

KKT $=$ Kapasitas Kerja teoritis (kg/jam)

$\mathrm{p} \quad=$ Panjang tahu $(\mathrm{m})$

$1=$ Lebar Tahu (m)

$\mathrm{BV}=$ Berat Volume $\left(\mathrm{kg} / \mathrm{m}^{3}\right)$

$$
\mathrm{V} \quad \underset{(\mathrm{m} / \mathrm{jam})}{=} \text { Kecepatan Pemotongan }
$$

\section{Efisiensi Alat Pomotong Tahu}

Efesiensi alat pemotong tahu dapat dihitung dengan menggunakan persamaan berikut :

$$
\eta=\frac{K K E}{K T} \times 100 \%
$$

Keterangan :

$$
\begin{aligned}
\eta & =\text { Efesiensi pemotongan } \% \\
\mathrm{KKE} & =\text { Kapasitas Kerja Efektif } \\
& (\mathrm{kg} / \mathrm{jam}) \\
\mathrm{KT} & =\text { Kapasitas Teoritis }(\mathrm{kg} / \mathrm{jam})
\end{aligned}
$$

\section{Persentase Terpotong Sempurna}

Persentase terpotong sempurna merupakan banyak tahu terpotong dari alat yang dinyatakan dalam persen. Indikasi tahu terpotong sempurna adalah bila ukuran tahu yang terpotong sesuai dengan ukuran yang diharapkan tanpa mengalami cacat sedikitpun. Pengukuran persentase tahu terpotong sempurna dapat dihitung dengan persamaan berikut:

$$
\mathrm{TS}=\frac{J T T S}{m} \times 100 \%
$$

Keterangan :

$$
\begin{array}{rlr}
\text { TS } & =\text { Persentase } & \text { Terpotong } \\
& \text { Sempurna }(\%) \\
\text { JTTS } & =\text { Jumlah tahu } & \text { terpotong } \\
& \text { sempurna }(\mathrm{kg}) \\
\mathrm{m} \quad & =\text { Berat tahu }(\mathrm{kg})
\end{array}
$$

\section{Persentase Kerusakan Hasil}

Kerusakan hasil didefinisikan sebagai proses pemotongan tahu yang menyebabkan tahu cacat/tidak terpotong sempurna. Persentase kerusakan hasil dapat dihitung menggunakan persamaan berikut :

$$
\mathrm{PKH}=\frac{B R T}{B T K} \times 100 \%
$$


Keterangan :

$$
\begin{aligned}
\text { PKH }= & \text { Persentase Kerusakan } \\
& \text { Hasil }(\%) \\
\text { BTR }= & \text { Berat tahu yang rusak }(\mathrm{kg}) \\
\text { BTK }= & \text { Berat tahu keseluruhan }(\mathrm{kg})
\end{aligned}
$$

\section{Persentase Kehilangan Hasil}

Persentase kehilangan hasil merupakan selisih antara berat tahu sebelum dipotong dan yang telah dipotong. Pengukuran persentase kehilangan hasil dapat dihitung menggunakan persamaan berikut :

$$
\mathrm{KH}=\frac{B A-B B}{B A} \times 100 \% \text {. }
$$

Keterangan:

$$
\begin{array}{ll}
\mathrm{KH} & =\text { Kehilangan hasil }(\%) \\
\mathrm{BA} & =\text { Berat Awal Tahu }(\mathrm{kg}) \\
\mathrm{BB} & =\text { Berat output }(\mathrm{kg})
\end{array}
$$

\section{Analisis Daya Operator}

Proses pemotongan tahu yang dilakukan secara manual maupun dengan menggunakan alat pasti memerlukan energi dari manusia. Manusia membutuhkan energy untuk melakukan suatu pekerjaan. Pengukuran denyut jantung operator setelah melakukan pemotongan, bertujuan untuk mengetahui berapa $\mathrm{kW}$ energy yang dikeluarkan untuk melakukan pemotongan. Denyut jantung pekerja dapat diukur dengan menggunakan alat Garmin Forerunner 35 dan Heart Rate Monitor (HRM).

\section{HASIL DAN PEMBAHASAN}

\section{Analisis Rancangan Ergonomi}

Manusia pada umumnya memiliki bentuk dan dimensi tubuh yang berbedabeda, maka dilakukan pengukuran pada anggota tubuh untuk dapat diaplikasikan dalam berbagai rancangan atau fasilitas kerja, seperti pada Gambar 4 [4].

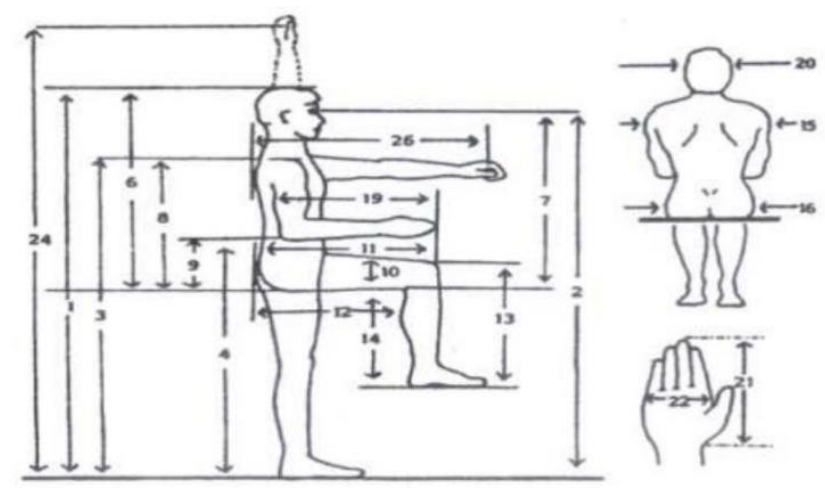

Gambar 4. Antropometri yang

Digunakan dalam Perancangan

Pengaplikasian data anthropometri ada beberapa prinsip yang harus ditetapkan terlebih dahulu, yaitu:

1. Perancangan fasilitas berdasarkan individu

2. Perancangan fasilitas yang bias disesuaikan

3. Perancangan fasilitas berdasarkan ukuran rata-rata

Data antropometri pada alat pemotong tahu dengan analisis tangkai penekan memperhatikan aspek ergonomic diantaranya

\section{a. Penentuan tinggi alat}

Pada perancangan alat memperhatikan data tinggi badan pada posisi berdiri tegak persentil 50 pria yaitu $1632 \mathrm{~mm}$ [5]. Desain tinggi meja kerja dapat dilihat pada Gambar 5.

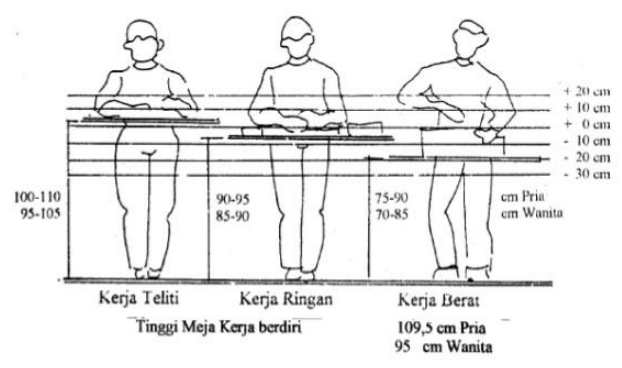

Gambar 5. Desain Meja Kerja 


\section{b. Penentuan Diameter Genggaman Tangan}

Perancanagan diameter genggaman tuas juga memperhatikan aspek antropometri persentil 50 yaitu diameter genggaman tangan maksimum $48 \mathrm{~mm}$ [5]. Beberapa antropometri tangan yang perlu diukur adalah [6]:

1. Panjang tangan

2. Panjang telapak tangan

3. Lebar tangan sampai ibu jari

4. Lebar tangan sampai matakarpal

5. Ketebalan tangan sampai matakarpal

6. Lingkar tangan sampai telunjuk

7. Lingkar tangan sampai ibu jari

Diameter genggaman tangan dapat dilihat pada Gambar 6.

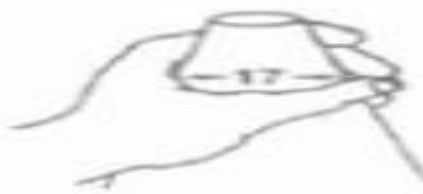

Gambar 6. Diameter Genggaman Tangan

\section{Analisis Antropometri}

Perhitungan analisis antropometri tinggi badan pada posisi tegak menggunakan rumus:

a. Menghitung Nilai Rata-rata

$$
\text { Xrerata }=\frac{\sum n}{n}
$$

Dimana :

Xrerata $=$ Rata-rata dimensi tubuh

$\sum \mathrm{n}=$ Total data dimensi tubuh

$\mathrm{n}=$ Jumlah data yang diambil

Tinggi badan pada posisi berdiri tegak berdasarkan data antropometri persentil 50\% adalah $1632 \mathrm{~mm}$. Maka diperoleh perhitungan :

$$
\text { Xrerata }=\frac{\sum \mathrm{n}}{\mathrm{n}}
$$

$$
\begin{aligned}
& =\frac{1632 \mathrm{~mm}}{1} \\
& =1632 \mathrm{~mm}
\end{aligned}
$$

b. Menghitung Standar Deviasi (SD)

$$
\mathrm{SD}=\sqrt{\frac{\sum(\text { Xrerata }-\mathrm{X})^{2}}{\mathrm{n}-1}}
$$

Dimana :

$$
\begin{array}{ll}
\mathrm{X} & =\text { Dimensi tubuh } \\
\mathrm{n} & =\text { Jumlah data yang } \\
\text { diambil } &
\end{array}
$$

Dimensi tinggi tubuh pada posisi berdiri tegak berdasarkan data antropometri persentil 50\% adalah $1632 \mathrm{~mm}$, maka diperoleh perhitungan:

$$
\begin{aligned}
\mathrm{SD} & =\sqrt{\frac{\sum(\text { Xrerata }-\mathrm{X})^{2}}{\mathrm{n}-1}} \\
\mathrm{SD} & =\sqrt{\frac{(1632 \mathrm{~mm}-1632 \mathrm{~mm})^{2}}{3-1}} \\
& =\sqrt{\frac{(0 \mathrm{~mm})^{2}}{2}} \\
& =\sqrt{0} \\
& =0 \mathrm{~mm}
\end{aligned}
$$

c. Menghitung Nilai Persentil 95\%

$$
\text { Px }=\text { Xrerata }+1,645(\text { SD) }
$$

Dimana:

Xrerata $=$ Nilai rata-rata dimensi tubuh

SD = Standar deviasi

$1,645=$ Nilai persentil 95

Px $\quad=$ Nilai persentil ke- $\mathrm{x}$ Maka diperoleh rancangan tinggi badan pada posisi berdiri tegak jika menggunakan persentil 95\%:

$$
\begin{aligned}
\text { Px } & =\text { Xrerata }+1,645(\mathrm{SD}) \\
& =1632 \mathrm{~mm}+1,645(61) \\
& =1632 \mathrm{~mm}+100,34 \\
& =1732,34 \mathrm{~mm}
\end{aligned}
$$

Data ini digunakan untuk perancangan tinggi alat pemotong jika menggunakan antropometri $95 \%$

d. Menghitung Nilai Persentil 5\%

$$
\mathrm{Px}=\text { Xrerata }-1,645(\mathrm{SD})
$$


Dimana :

Xrerata $=$ Nilai rata-rata dimensi tubuh

SD = Standar deviasi

$1,645=$ Nilai persentil 95

$\mathrm{Px} \quad=$ Nilai persentil ke-X

Maka diperoleh rancangan tinggi badan pada posisi berdiri tegak jika menggunakan persentil 5\%:

$$
\begin{aligned}
\text { Px } & =\text { Xrerata }-1,645(\mathrm{SD}) \\
& =1632 \mathrm{~mm}-1,645(61) \\
& =1632 \mathrm{~mm}-100,34 \\
& =1531,66 \mathrm{~mm}
\end{aligned}
$$

Data ini digunakan untuk perancangan tinggi alat jika menggunakan data antropometri $5 \%$.

Perhitungan analisis antropometri diameter genggaman tangan menggunakan rumus :

a. Menghitung Nilai Rata-rata

$$
\text { Xrerata }=\frac{\sum \mathrm{n}}{\mathrm{n}}
$$

Dimana :

Xrerata $=$ Rata-rata dimensi tubuh

$\sum \mathrm{n} \quad=$ Total data dimensi tubuh

$\mathrm{n} \quad=$ Jumlah data yang diambil

Diameter genggaman tangan berdasarkan data antropometri persentil 50\% adalah $48 \mathrm{~mm}$. Maka diperoleh perhitungan :

$$
\begin{aligned}
\text { Xrerata } & =\frac{\sum \mathrm{n}}{\mathrm{n}} \\
& =\frac{48 \mathrm{~mm}}{1} \\
& =48 \mathrm{~mm}
\end{aligned}
$$

b. Menghitung Standar Deviasi (SD)

$$
\mathrm{SD}=\sqrt{\frac{\sum(\text { Xrerata }-\mathrm{X})^{2}}{\mathrm{n}-1}}
$$

Dimana :

$$
\begin{array}{ll}
\mathrm{X} & =\text { Dimensi tubuh } \\
\mathrm{n} & =\text { Jumlah data yang } \\
\text { diambil } &
\end{array}
$$

Diameter genggaman tangan berdasarkan data antropometri persentil
50\% adalah $48 \mathrm{~mm}$, maka diperoleh perhitungan:

$$
\begin{aligned}
\mathrm{SD} & =\sqrt{\frac{\sum(\text { Xrerata }-\mathrm{X})^{2}}{\mathrm{n}-1}} \\
\mathrm{SD} & =\sqrt{\frac{(48 \mathrm{~mm}-48 \mathrm{~mm})^{2}}{3-1}} \\
& =\sqrt{\frac{(0 \mathrm{~mm})^{2}}{2}} \\
& =\sqrt{0} \\
& =0 \mathrm{~mm}
\end{aligned}
$$

c. Menghitung Nilai Persentil 95\%

$$
\text { Px = Xrerata + 1,645(SD) }
$$

\section{Dimana :}

Xrerata $=$ Nilai rata-rata dimensi tubuh

SD $=$ Standar deviasi

$1,645=$ Nilai persentil 95

Px = Nilai persentil ke- $\mathrm{X}$

Maka diperoleh rancangan diameter genggaman tangan jika menggunakan persentil 95\%:

$$
\begin{aligned}
\mathrm{Px} & =\text { Xrerata }+1,645(\mathrm{SD}) \\
& =48 \mathrm{~mm}+1,645(2) \\
& =48 \mathrm{~mm}+3,29 \\
& =51,29 \mathrm{~mm}
\end{aligned}
$$

Data ini digunakan untuk perancangan genggaman tuas pemotong jika menggunakan antropometri $95 \%$

d. Menghitung Nilai Persentil 5\%

$$
\mathrm{Px}=\text { Xrerata }-1,645(\mathrm{SD})
$$

\section{Dimana :}

Xrerata $=$ Nilai rata-rata dimensi tubuh

$$
\begin{array}{ll}
\mathrm{SD} & =\text { Standar deviasi } \\
1,645 & =\text { Nilai persentil } 95 \\
\mathrm{Px} & =\text { Nilai persentil ke-X }
\end{array}
$$

Maka diperoleh rancangan diameter genggaman tangan jika menggunakan persentil 5\%:

$$
\begin{aligned}
\text { Px } & =\text { Xrerata }-1,645(\mathrm{SD}) \\
& =48 \mathrm{~mm}-1,645(2) \\
& =48 \mathrm{~mm}-3,29 \\
& =44,71 \mathrm{~mm}
\end{aligned}
$$

Data ini digunakan untuk perancangan diameter genggaman tangan tuas 
pemotong menggunakan antropometri $5 \%$

\section{Hasil Rancangan Alat Pemotong Tahu Semi Mekanis}

Alat pemotong tahu semi mekanis dalam penelitian ini menggunakan beberapa komponen sebagai sarana pendukung agar kinerja alat dapat berfungsi dengan baik. Alat pemotong tahu semi mekanis ini bertujuan untuk mempercepat waktu pemotongan tahu dan mengurangi kecelakaan terjadinya luka pada pekerja. Alat pemotong tahu semi mekanis dapat dilihat pada Gambar 7.

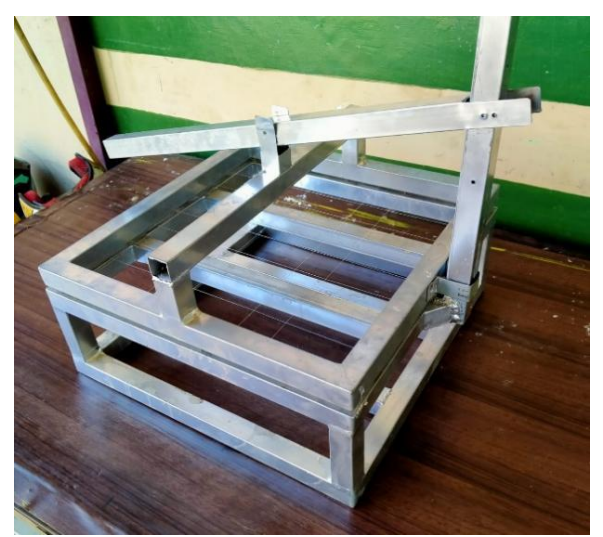

Gambar 7. Alat Pemotong Tahu Semi Mekanis

Alat pemotong tahu semi mekanis ini terdiri dari beberapa bagian, yaitu:

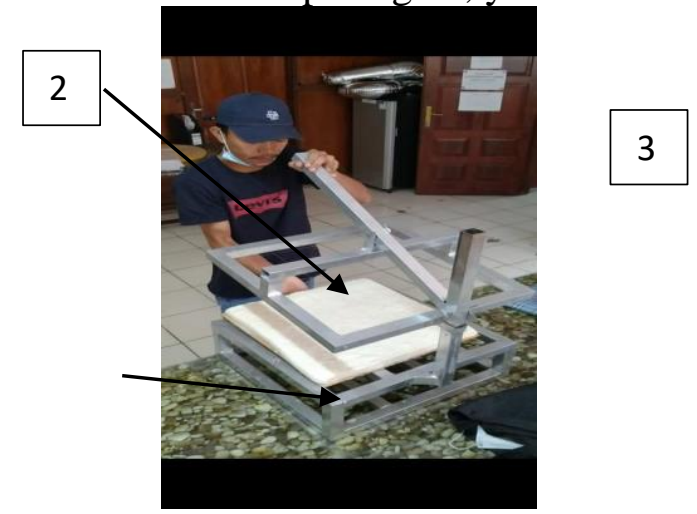

Gambar 8. Komponen Alat Pemotong Tahu

\section{Rangka Utama}

Rangka Utama merupakan bagian dudukan komponen-komponen dari alat pemotong tahu semi mekanis, dimana bahan yang digunakan yaitu besi hollow yang di las membentuk balok dengan ukuran $45 \mathrm{~cm} \mathrm{x} 45 \mathrm{~cm}$ dengan tinggi $40 \mathrm{~cm}$. rangka utama berfungsi sebagai penopang umtuk menahan komponen lainnya sekaligus sebagai dudukan tahu.

\section{Senar Pemotong}

Kawat/ senar gitar adalah bagian yang berfungsi untuk memotong tahu, banyak kawat pemotong/ senar gitar untuk perlakuan pertama yaitu 10 kawat dengan ukuran potongan tahu $10 \mathrm{~cm}$ x 5 $\mathrm{cm}$ dan perlakuan kedua sebanyak 14 kawat untuk ukuran potongan tahu $5 \mathrm{~cm}$ $\mathrm{x} 5 \mathrm{~cm}$.

\section{Tuas Pemotong}

Tuas pemotong berfungsi untuk menekan rangka senar pemotong yang terletak pada bagian paling atas dari rangka utama dan rangka senar pemotong. Tuas pemotong mengunakan bahan besi hollow.

\section{Uji Teknis Alat Pemotong Tahu}

Uji teknis alat pemotong tahu semi mekanis bertujuan untuk menguji kerja alat yang dibuat apakah alat bekerja atau tidak. Pengujian alat pemotong tahu meliputi beberapa pengamatan yaitu:

\section{Kadar Air tahu}

Kadar air merupakan banyaknya kandungan air yang terdapat pada tahu dengan satuan persen. Data kadar air dapat dilihat pada Gambar 9. 


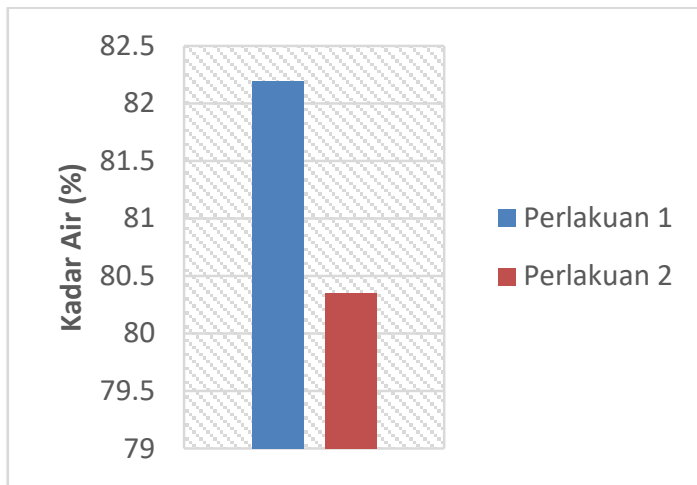

Gambar 9. Rata-rata Kadar Air Tahu

Berdasarkan data yang didapatkan, nilai kandungan kadar air rata-rata tahu pada P1 lebih besar dari nilai rata-rata kadar air pada perlakuan P2, yaitu P1 $(82,19 \%)$ dan P2 (80,35\%). Menurut [7] kadar air tahu berkisar antara 80,18\% sampai $83,17 \%$.

\section{Kapasitas Kerja Efektif}

Kapasitas kerja efektif pemotong yaitu kemampuan alat pemotong persatuan waktu. Hasil pengamatan kapasitas kerja efektif alat pemotong tahu dapat dilihat pada Gambar 10.

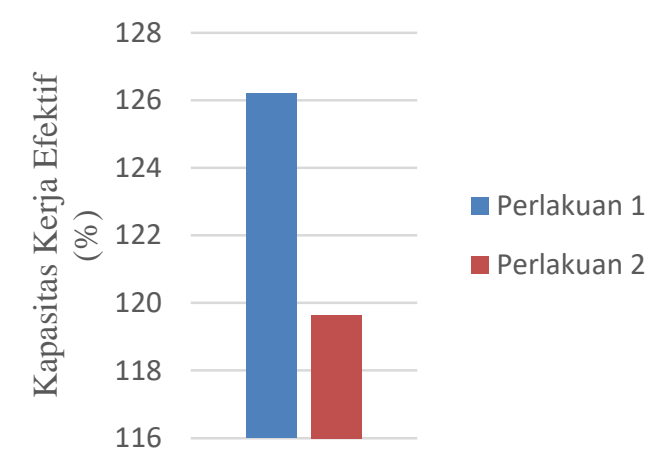

Gambar 10. Rata-rata Kapasitas Kerja Efektif

Berdasarkan data yang didapatkan dari hasil pengujian alat pemotong tahu semi mekanis, nilai rata-rata kapasitas kerja efektif pada perlakuan P1 (126,2 $\mathrm{kg} / \mathrm{jam})$ dan P2 (119,64 kg/jam) adalah berbeda. Perbedaan nilai kapasitas kerja efektif pada pemotongan dipengaruhi oleh berat tahu setelah dicetak dan ukuran tahu yang akan dipotong berbeda. Hal lain yang mempengaruhi nilai rata-rata kapasitas kerja efektif yaitu kecepatan pengoperasian alat dari sang operator, karena kecepatan berbeda sehingga waktu yang dibutuhkan tiap pengulangan dan perlakuan juga berbeda.

\section{Kapasitas Teoritis}

Kapasitas kerja teoritis alat pemotong tahu semi mekanis yang didapatkan berdasarkan sampel yang uji pada saat dilakukannya penelitian. Nilai kapasitas kerja teoritis yang didapatkan pada P1 (145,73 kg/jam) dan P2 $(155,736 \quad \mathrm{~kg} / \mathrm{jam}) . \quad$ Berdasarkan pengamatan dan hasil perhitungan kapasitas kerja teoritis alat pemotong tahu dapat dilihat pada Gambar 11.

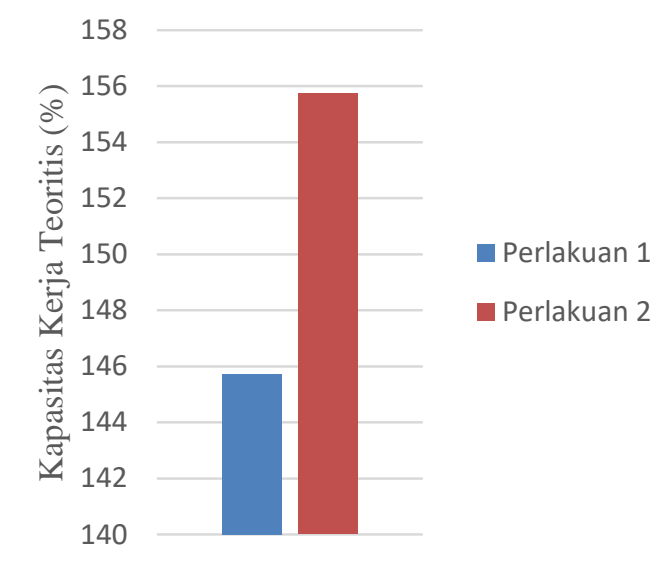

Gambar 11. Rata-rata Kapasitas Kerja Teoritis

\section{Efesiensi Alat Pemotong Tahu}

Efesiensi alat pemotong tahu merupakan perbandingan antara kapasitas kerja efektif dan kapasitas kerja teoritis yang didapatkan dari alat pemtong tahu. Berdasarkan dari pengamatan dan hasil pehitungan yang dilakukan terhadap alat pemotong tahu yang dapat dilihat pada Gambar 12. 


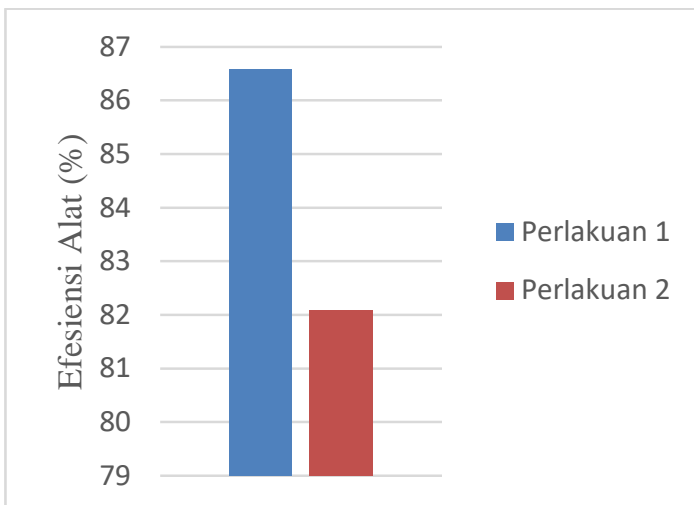

Gambar 12. Rata-rata Persentase Efesiensi Alat

Berdasarkan data yang didapatkan, nilai rata-rata efesiensi alat pemotong tahu yang ditunjukkaan pada dua perlakuan yaitu P1 (86,578 \%) dan P2 $(82,08 \%)$. Hal ini menunjukan bahwa alat pemotong tahu semi mekanis lebih efesien dari alat pemotong yang manual yaitu 26,50 \%. Berdasarkan Gambar 12, nilai rata-rata efesiensi alat pemotong tahu tertinggi pada perlakuan 1 yaitu $86,578 \%$, Perbedaan nilai rata-rata efesiensi disebabkan oleh nilai kapasitas keja efektif yang berbeda sehingga nilai persentase efesiensi alat juga berbeda.

\section{Persentase Terpotong Sempurna}

Persentase terpotong sempurna pemotongan tahu ditentukan dengan cara melihat hasil yang terpotong dari hasil pemotongan oleh alat pemotong tahu. Persentase yang dihasilkan dari berat tahu yang terpotong sesuai dengan ukuran pemotongan dibandingkan dengan berat awal tahu sebelum dilakukannya pemotongan. Data pensentase terpotong sempurna dapat dilihat pada Gambar 13.

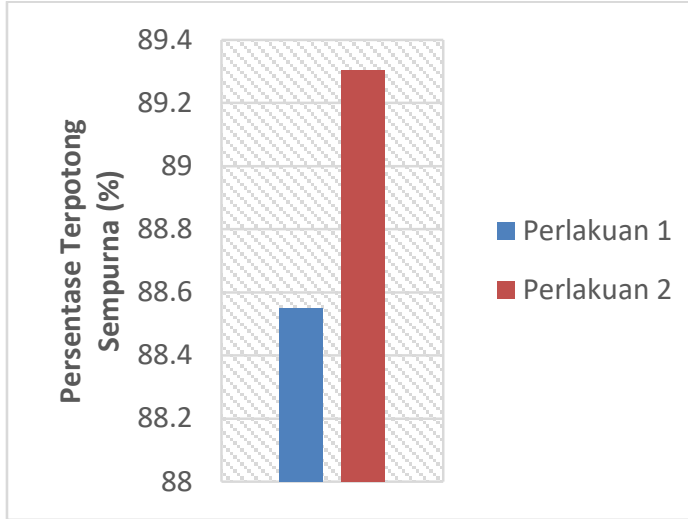

Gambar 13. Rata-rata Persentase Terpotong Sempurna

Berdasarakan data yang didapatkan dari pengujian alat pemotong tahu semi mekanis, nilai rata-rata persentase terpotong sempurna antara P1 $(88,54 \%)$ dan P2 (89,30\%) adalah berbeda, hal ini dipengaruhi oleh tahu yang dipotong menggunakan perlakuan yang berbeda, dimana pada P1 dilakukan pemotongan yang menghasilkan potongan tahu dengan ukuran $10 \mathrm{~cm}$ x 5 $\mathrm{cm}$, sedangkan untuk P2 dilakukan pemotongan dengan ukuran $5 \mathrm{~cm}$ x 5 $\mathrm{cm}$, sehingga berat satu potong tahu yang hasil potongannya sempurna/tanpa cacat sedikitpun antara P1 dan P2 juga berbeda.

\section{Persentase Kerusakan Hasil}

Persentase kerusakan hasil pemotongan tahu ditentukan dengan cara melihat hasil potongan yang rusak/tidak utuh. Persentase yang dihasilkan dari berat tahu yang rusak dibandingkan dengan berat awal tahu. Data persentase kerusakan hasil dapat dilhat pada Gambar 14. 


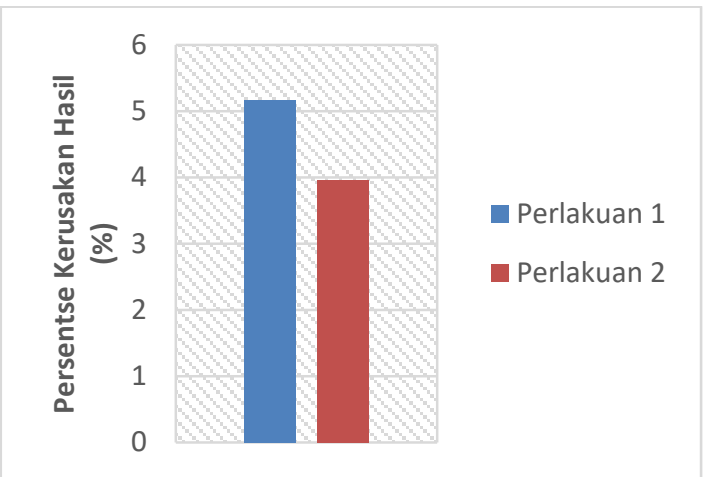

Gambar 14. Rata-rata Persentase Kerusakan Hasil

Berdasarkan data pengamatan dan perhitungan yang didapatkan nilai persentase kerusakan hasil antara P1 $(5,16 \%)$ dan P2 (3,96\%). Hal ini dipengaruhi oleh potongan tahu yang menggunakan perlakuan yang berbeda, dimana pada perlakuan P1 menggunakan ukuran pemotongan $10 \mathrm{~cm}$ x $5 \mathrm{~cm}$, sedangkan untuk perlakuan P2 menggunakan ukuran pemotongan $5 \mathrm{~cm}$ x $5 \mathrm{~cm}$ dan pada saat mobilisasi tahu ke tempat penelitian, terjadi benturan terhadap tahu yang menyebabkan kecacatan terhadap tahu itu sendiri, sehingga terdapat hasil potongan tahu yang yang sumbing/tidak memenuhi kriteria ukuran potongan tahu yang telah ditentukan.

\section{Persentase Kehilangan Hasil}

Persentase kehilangan hasil dalam pengamatan yang dilakukan dengan cara membandingkan berat sampel yang dikurangi output dengan berat sampel tahu. Data persentase kehilangan hasil dapat dilihat pada Gambar 15.

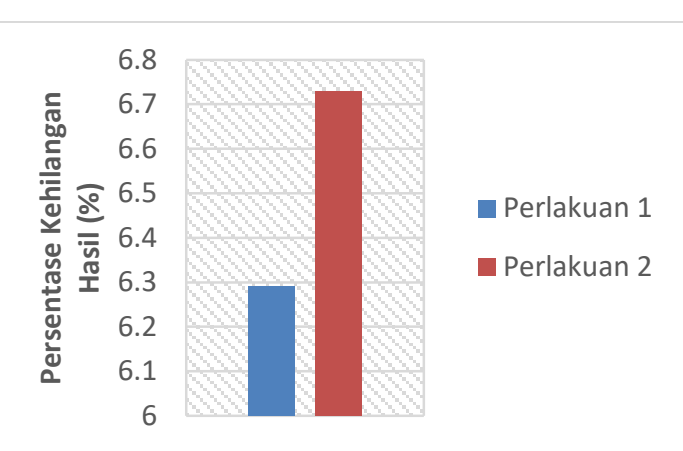

Gambar 15. Rata-rata Persentase Kehilangan Hasil

Berdasarkan data yang didapatkan, persentase kehilangan hasil pada P1 dan P2 beturut-turut adalah $6,29 \%$ dan $6,72 \%$, hal ini menunjukkan pada kedua perlakuan hanya sedikit selisih persentase kehilangan hasilnya. Hal ini dipengaruhi pada saat tahu dipindahkan dari cetakan ke talenan untuk dipotong dengan alat pemotong, ukuran tahu mengalami sedikit perubahan dari ukuran cetakan tahu karena tahu memiliki fisik yang lunak, sehingga tahu yang akan dipotong melebihi ukuran frame dari alat pemotong itu sendiri yang menyebabkan sisa potongan tahu tidak bisa dipasarkan karena ukurannya tidak memenuhi batas ukuran yang telah ditentukan.

\section{Analisis Daya Operator}

Pengukuran daya operator dilakukan untuk mengetahui berat ringannya suatu pekerjaan yang dilakukan oleh operator berdasarkan pengukuran denyut nadi per menit. Dengan menggunakan Garmin Foreruner 35 dan Stopwatch denyut nadi operator dapat dicatat. Denyut nadi sesudah bekerja dapat dicocokkan dengan table tingkat beban kerja yang didasarkan pada denyut jantung manusia berumur 20-50 tahun. Tabel kategori beratnya suatu pekerjaan dapat dilihat 
pada Tabel 2. Data pengukuran daya operator dapat dilihat pada Gambar 16.

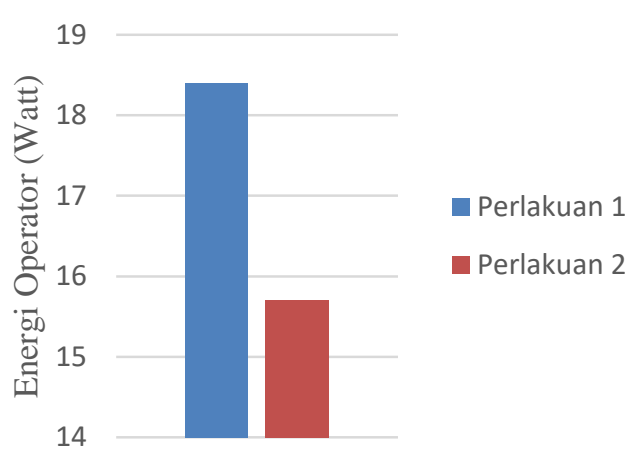

Gambar 16. Rata-rata Daya Operator

Pengukuran denyut nadi pada saat pemotongan didapatkan nilai rata-rata pada perlakuan pertama dan perlakuan kedua didapatkan 67,6 denyut/menit dan 64,8denyut/menit, keduanya termasuk dalam kategori tingkat kerja sangat ringan. Daya yang dihasilkan berdasarkan perhitungan interpolasi, daya semi mekanis rata-rata $18,396 \mathrm{~W}$ dan 15,708 W. Hal ini dipengaruhi oleh berat tahu yang diangkat ke alat pemotong yang lumayan berat, sehingga membuat denyut nadi sedikit mengencang.

\section{KESIMPULAN}

Berdasarkan penelitian yang telah dilaksanakan dapat disimpulkan bahwa :

1. Telah dihasilkan pengembangan alat pemotong tahu semi mekanis dengan memperhatikan aspek ergonomic, tinggi alat, lebar alat, lamanya waktu pengoperasian alat.

2. Hasil pengujian dengan 2 jenis perlakuan untuk pemotongan tahu yang mempunyai ukuran $10 \mathrm{~cm} \times 5$ cm dengan nilai rata-rata kapasitas kerja efektif sebesar 126,2 kg/jam dan nilai rata-rata kapasitas kerja efektif untuk ukuran pemotongan 5 $\mathrm{cm} \times 5 \mathrm{~cm}$ sebesar 119,64 kg/jam, sedangkan nilai rata-rata efesiensi alat berturut-turut sebesar 74,08\% dan $70,23 \%$.

3. Analisis ekonomi yang telah dilakukan, didapatkan biaya tetap pada alat pemotong tahu sebesar Rp 196.000 / tahun, sedangkan biaya tidak tetap sebesar Rp 6394 / jam, dan biaya pokok sebesar Rp $5 / \mathrm{kg}$

\section{DAFTAR PUSTAKA}

[1] Susanto, A., Perancangan Meja Kerja untuk Alat Pres Plastik yang Ergonomis Menggunakan Metode Rasional dan Pendekatan Anthropometri. Jurnal Ilmiah Teknik Industri, 2014.

[2] Tarwaka, S.H.A. Bakri, and L. Sudiajeng, Ergonomi untuk Keselamatan, Kesehatan Kerja dan Produktivitas. 2004, Malang: Universitas Brawijaya Press.

[3] Nugroho, M., N. Adi, and A.K.A. Ghofari, Perancangan Alat Pemotong Tahu dengan Metode Benchmarking, in Doktoral. 2018, Universitas Muhammadiyah:

Surakarta.

[4] Wignjosoebroto, S., Ergonomi, Studi Gerak dan Waktu. 1995, Jakarta: Guna Widya.

[5] Nurmianto, E., Ergonomi, Konsep Dasar, dan Aplikasinya. 1991, Surabaya: Guna Widya.

[6] Liliana, Y. Pertimbangan Antropometri pada Pendisainan. in Seminar Nasional III SDM Teknologi Nuklir. 2007. Yogyakarta.

[7] Andarwulan, N., Pengaruh Perbedaan Jenis Kedelai terhadap Kualitas Mutu Tahu, in Ilmu dan Teknologi Pangan. 2018, Institut Pertanian Bogor: Bogor. 